\title{
Artotrogus gordoni n. sp. (Copepoda: Siphonostomatoida: Artotrogidae) Assocaited with the Bryozoan Schizosmittina cinctipora (Hincks) from New Zealand
}

\author{
Il-Hoi Kim* \\ Department of Biology, Kangnung National University, Gangnung 210-702, Korea
}

\begin{abstract}
Artotrogus gordoni n. sp. is described as an associate of the bryzoan Schizosmittina cinctipora (Hincks, 1885) collected from an intertidal shore in New Zealand. The new species is similar to A. sardae McKinnon but distinguishable from it by the different shapes of antennule where the first segment is the longest and urosome where the anal somite is distinctly narrower than the genital double somite and posterolateral processes on the genital double somite which is tapered and much more developed than in A. sardae.
\end{abstract}

Key words: Artotrogus gordoni, n. sp., Artotrogidae, Siphonostomatoida, New Zealand

\section{INTRODUCTION}

Jones and Marshall (1986) mentioned that the copepod associates of New Zealand marine invertebrates are poorly known and 17 species had been described from this country until that time, not including Cocculinika myzorama they described.

The siphonostoamtoid copepod genus Artotrogus Boeck, 1859, the type genus of the family Artotrogidae, may be characterized by the possession of a circular, disk-shaped body, two inner setae on the second endopodal segment of leg 1 , no leg 4, and an antennary exopod reduced to a papilla bearing one seta (Boxshall and Halsey, 2004). The genus consists of 10 described species (Kim, 1996) from the northwestern Europe, Mediterranean, Australia, and the Far East. Known hosts of Artotrogus include nudibranch mollusks for A. orbucularis and A. sarsi (Boeck, 1859; Sars, 1915), an ascidian for A. incidentus and A. halocynthiae (Kim, 1996), and a bryozoan for A. acutus and A. rotundus (Kim, 1996).

From the South Pacific, three species of the genus has been described: A. latifurcatus by Nicholls (1944) and $A$. haikungae and $A$. sardae by McKinnon (1988), all from the Australian waters. In this paper a new species of Artotrogus is described as the first record of the genus from the New Zealand region.

Schizosmittina cinctipora (Hincks) (Cheilostomata: Bitectiporidae) is a common shelf bryozoan that is widely distributed around New Zealand from the Kermadec Ridge to subantarctic Auckland and Campbell Islands. As an encrust-

*To whom correspondence should be addressed

Tel: 82-33-640-2312, Fax: 82-33-642-6124

E-mail: ihkim@kangnung.ac.kr ing species of rocky and shelly substrata, it is found from 0 $253 \mathrm{~m}$ depth.

\section{MATERIALS AND METHODS}

The specimen had been preserved in $10 \%$ formalin until the microscopic observation, after then it has been preserved in $80 \%$ ethanol. Before measuring and dissection, the specimen was soaked in lactic acid for more than 30 minutes. The dissection was done using the reverse slide method of Humes and Gooding (1964). Drawings were made with the aid of a camera lucida. The urosome of the specimen was drawn in situ.

\section{SYSTEMATIC ACCOUNTS}

Order Siphonostomatoida Burmeister, 1835

Family Artotrogidae Brady, 1880

Genus Artotrogus Boeck, 1859

Artotrogus gordoni n. sp. (Figs. 1, 2)

Material examined. 1 우 holotype (NIWA 35328; appendges of left side dissected out and mounted on a slide) from washings of the bryozoan Schizosmittina cinctipora (Hincks, $1885)$ collected at intertidal shore (0-1 m) of Station Z15308 $\left(41^{\circ} 20^{\prime} 47^{\prime \prime} \mathrm{S}, 174^{\circ} 46^{\prime} 58^{\prime \prime} \mathrm{E}\right)$, New Zealand, by Dr. Dennis P. Gordon, on 14 January 2008. The holotype (partly dissected, with intact urosome, mandibles, and other appendages of right side) and slide mount containing dissected appendages of holotype have been deposited in the National Insti- 


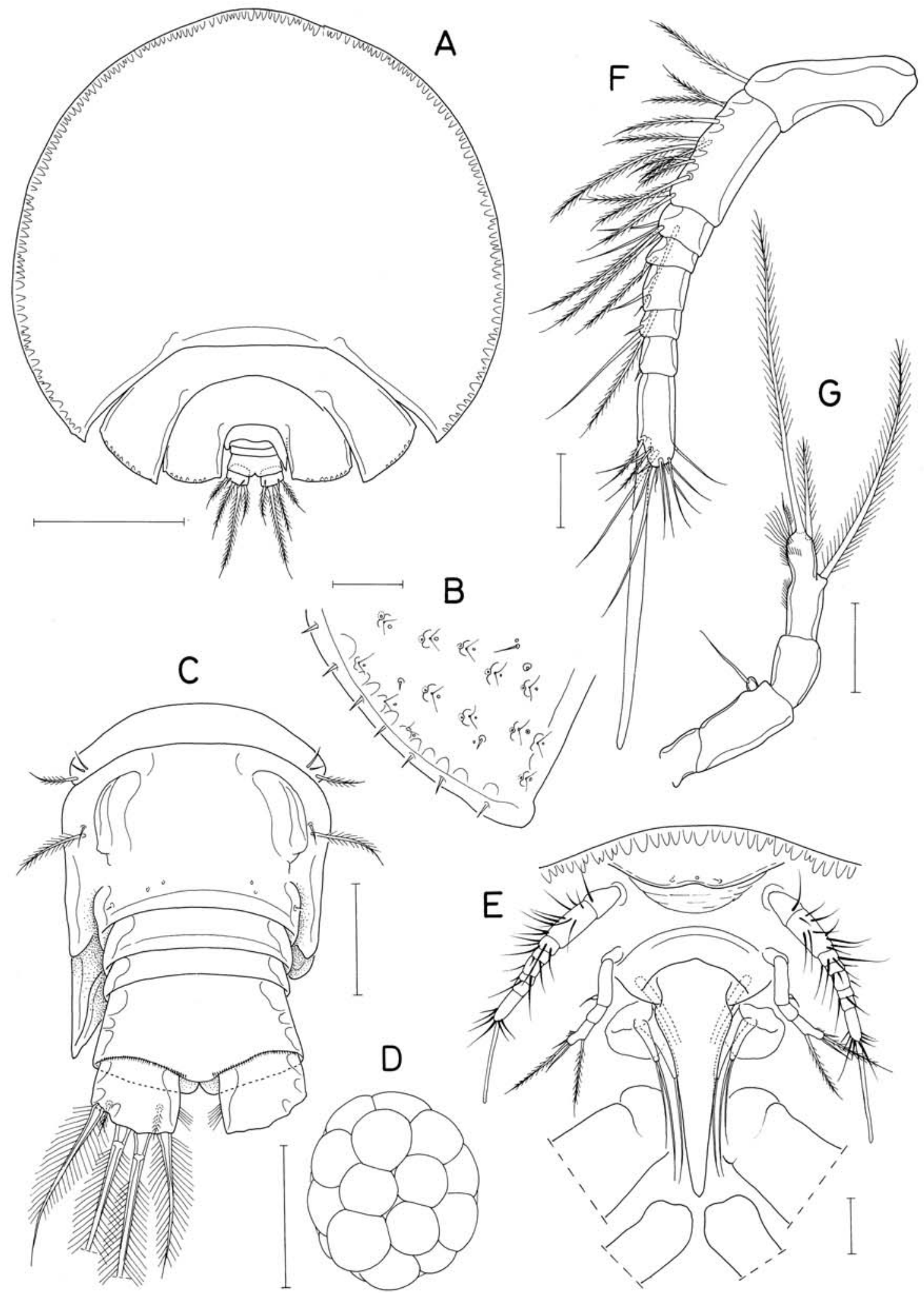

Fig. 1. Artotrogus gordoni n. sp., female. A, habitus, dorsal; B, posterolateral part of epimera of second pedigerous somite showing dorsal ornamentation; C, urosome, ventral (in situ); D, egg sac; $\mathrm{E}$, oral area, ventral; $\mathrm{F}$, antennule; $\mathrm{G}$, antenna. Scales bars $=0.5$ $\mathrm{mm}(A, D), 0.05 \mathrm{~mm}(B, F, G), 0.1 \mathrm{~mm}(C, E)$. 

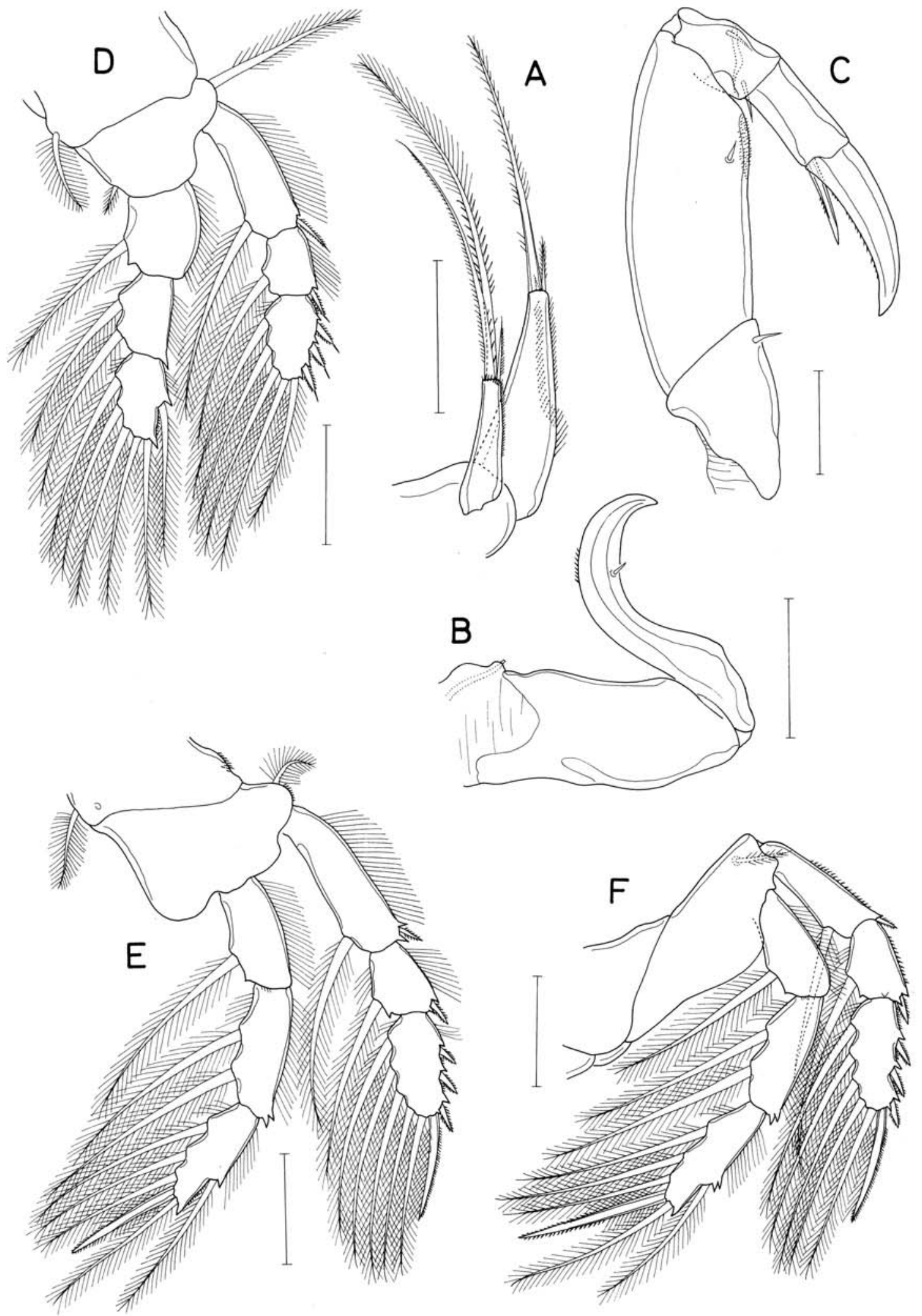

Fig. 2. Artotrogus gordoni n. sp., female. A, maxillule; B, maxilla; C, maxilliped; D, leg 1 ; $E$, leg 2; F, leg 3 . Scales bars=0.1 mm (A-F). 
tute of Water and Atmosphere, New Zealand.

Female. Body (Fig. 1A), circular, dorsoventrally flat, and disk-shaped. Body length $1.59 \mathrm{~mm}$, excluding setae on caudal rami. Maximum width of body $1.61 \mathrm{~mm}$. Prosome consisting of cephalothorax, second pedigerous somite, and third pedigerous somite. Fourth pedigerous somite not seen in both dorsal and ventral views. Cephalothorax large, 1.12 $\mathrm{mm}$ long (measured along middle axis), occupying about $70 \%$ length of whole body, with pointed posterolateral corners, with slightly pronounced anterior apex. Epinera of second pedigerous somite gradually broadened laterally, its posterolateral tip extending over epimera of third pedigerous somite. Third pedigerous somite reversed U-shaped, its posterior margin extending to level of middle of caudal rami. Dorsal surface of tergite of prosomal somites ornamented with simple spinules, sensillum accompanied by minute nearby pore, paired hair-like sensillae in pit accompanied by nearby minute pore(s) (Fig. 1B).

Urosome (Fig. 1C) 5-segmented. Fifth pedigerous somite short. Genital double somite $146 \times 242 \mu \mathrm{m}$ (measured along middle axis of ventral side), consisting of broader anterior part and short narrower posterior part (this part $187 \mu \mathrm{m}$ wide and not seen in dorsal view of urosome), asymmetrical in having large, tapering (in dorsal and ventral views) posterolateral process on right side and small, lobate posterolateral process on left side (Fig. 1C); genital area located ventrally. Three free abdominal somites $35 \times 171,24 \times 171$, and 104 $\times 188 \mu \mathrm{m}$. Anal somite with row of minute spinules along posteroventral border. Caudal ramus $63 \times 78 \mu \mathrm{m}$ (1: 1.24), with patch of setules on inner margin and 6 plumose setae; 2 dorsal ones of caudal setae distinctly smaller than other 4 . Egg sac $700 \times 608 \mu \mathrm{m}$, disk-shaped, and containing 24 eggs; each egg $223 \mu \mathrm{m}$ in diameter.

Rostrum broad but short, directed ventrally, with W-shaped ventral margin (Fig. 1E). Antennule (Fig. 1F) $367 \mu \mathrm{m}$ and 8-segmented, with armature formula 1, 11, 6, 2, 2, 2, 1, and $14+$ aesthetasc; setae usually weakly plumose; seta on seventh segment minute; lengths of segments 96, 87, 23, 18, 29, 17,24 , and $63 \mu \mathrm{m}$ from proximal to distal; aesthetasc on last segment $212 \mu \mathrm{m}$ long. Antenna with unarmed coxa of $25 \times 15 \mu \mathrm{m}$; basis $53 \times 29 \mu \mathrm{m}$, gradually widend distally. Exopod small, $7.5 \times 6.7 \mu \mathrm{m}$, nipple-shaped, with 1 smooth distal seta. Endopod 2-segmented; proximal segment unarmed and $33 \times 26 \mu \mathrm{m}$; distal segment $58 \times 20 \mu \mathrm{m}(2.90: 1), 1.76$ times as long as proximal segment, with 1 inner lateral seta (143 $\mu \mathrm{m}$ long) and 3 unequal distal setae (56, 183, and 23 $\mu \mathrm{m}$ long respectively from inner to outer); largest distal seta fused with segment at base.

Oral siphon $423 \mu \mathrm{m}$ long, tapering, and extending over insertion of maxillae but not reaching insertion of maxilliped (Fig. 1E). Mandible inserting to oral siphon. Maxillule (Fig.
2A) bilobed; outer lobe $85 \times 27 \mu \mathrm{m}$ and armed with 3 distal setae (171, 231, and $40 \mu \mathrm{m}$ long respectively), largest one of them slightly extending over tip of largest seta on inner lobe and spinulated proximally and plumose distally; inner lobe $133 \times 51 \mu \mathrm{m}$ and distinctly tapering, with 3 distal setae, one of them minute and hardly seen, other two 173 and $35 \mu \mathrm{m}$ long respectively. Maxilla (Fig. 2B) consisting of proximal segment and distal claw; distal claw strong, strongly curved, with several spinules on convex side and small seta on concave side. Maxilliped (Fig. 2C) consisting of 4 segments and distal claw; first segment with small inner distal seta; second segment with small subdistal seta and patch of minute spinules near seta; third segment with rudiment of segmentation on ventral side and 2 setae; fourth segment with spiniform distal seta; distal claw massive, with spinules on concave margin. Distal part of claw of maxilla and maxilliped tinted with orange color.

Legs 1-3 (Fig. 2D-F) with 3-segmented rami. Leg 4 lacking. Second endopodal segment of legs 2 and 3 with bicuspid outer distal corner. Third endopodal segment of leg 3 with bicuspid process on middle of outer margin at base of outer seta. Leg 3 with exopod ornamented with spinules on outer margin but those of legs 1 and 2 with setules. Distal spine on endopod of legs 2 and 3 plumose proximally but spinulated distally. Armature formula of legs 1-3 as follows:

Leg 1 : coxa $0-1$; basis $1-1$; exopod I-1; I-1; III,2,3; endopod $0-1 ; 0-2 ; 1,2,3$

Leg 2 : coxa $0-1$; basis $1-0$; exopod I-1; I-1; III,I,5; endopod $0-1 ; 0-2 ; 1,1+\mathrm{I}, 3$

Leg 3 : coxa 0-0; basis 1-0; exopod I-1; I-1; III,I,5; endopod $0-1 ; 0-2 ; 1,1+\mathrm{I}, 3$

Leg 5 represented by 1 plumose and 2 small setae on ventrolateral side of fifth pedigerous somite (Fig. 1C). Leg 6 represented by plumose seta and setule located lateral to genital area (Fig. 1C).

Male. Unknown.

Etymology. The new species is named after Mr. Dennis Gordon who collected the type specimen.

\section{DISCUSSION}

In most species of Artotrogus the third endopodal segment of leg 2 has one spine and five setae (armature formula 1, 1+I, 3), except for A. incidentus Kim, 1996 which has six setae (formula 1, 2, 3) and A. latifurcatus Nicholls, 1944 which is not known for leg 2 . The armature formula of the third endopodal segment of leg 3 is variable among species: 1, I, 3 in A. orbicularis Boeck, 1859 (see Giesbrecht, 1899); 1, 1+I, 3 in A. acutus Kim, 1996 and A. sardae McKinnon, 1988; 1, 2, 2 in A. halocynthiae Kim, 1996 and A. sarsi Kim, 
1996; and 1,2, 3 in A. gladiator (Giesbrecht, 1899), A. haikungae McKinnon, 1988, A. incidentus, A. latifurcatus, and A. rotundus Kim, 1996. Therefore, only two species, A. acutus and $A$. sardae, are known to have the armature formula $1,1+\mathrm{I}, 3$ on the third endopodal segment of both legs 2 and 3, as in A. gordoni n. sp.

Artotrogus gordoni differs from A. acutus in having a seta on the posterior margin of the basis of leg 1 (lacking a seta in A. acutus), three spines and five setae (formula III, 2, 3, in contrast to II, 2, 3 in A. acutus), and no seta on the coxa of leg 3 (a seta present in A. acutus).

Artotrogus gordoni seems most close to A. sardae in having the same armature formula of legs 1-3. Both species were found in the same zoogeographical region, as well. However, they can be differentiated by the following ways: although the antennule of the female is eight-segmented in both species, its longest segment is the first one in A. gordoni but the second one in $A$. sardae; the anal somite is narrower than the genital double somite in A. gordoni; in A. gordoni the genital double somite bears the short and narrow posteroventral portion which is not reported in A. sardae; the posterolateral process on each side of the genital double somite is much more developed in A. gordoni than in $A$. sardae.

The process on the genital double-somite is frequent in Artotrogus and tapered as in A. gordoni or roundly ended as in A. sardae. Interestingly, in both A. gordoni and A. sardae one of two processes is atrophied in relation to the other. This asymmetry is considered to be the result of an accidental lost of one of the processes.

\section{ACKNOWLEDGEMENTS}

I am very grateful to Dr. Janet M. Bradford-Grieve, the Emeritus Researcher, National Institute of Water and Atmospheric Research, for providing the author the copepod specimen and to Dr. Dennis P. Gordon, the Principal Scientist, Aquatic Biodiversity \& Biosecurity, the same institute, for collecting the specimen.

\section{REFERENCES}

Boeck, A., 1859. Tvende nye parasitiske Krebsdyr, Artotrogus orbicularis og Asterocheres liljeborgii. Forh. Vidensk. Selsk. Krist., 1859: 171-182, pls. 1, 2.

Boxshall, G.A. and S.H. Halsey, 2004. An Introduction to Copepod Diversity, Part II. The Ray Society, London, pp. 422966.

Giesbrecht, W., 1899. Die Asterocheriden des Golfes von Neapel. Fauna Flora Golf. Neapel, 25: 1-217.

Humes, A.G. and R.U. Gooding, 1964. A method for studying the external anatomy of copepods. Crustaceana, 6(3): 238240.

Jones, J.B. and B.a. Marshall, 1986. Cocculinika myzorama, new genus, new species, a parasitic copepod from a deepsea wood-ingesting limpet. J. Crustacean Biol., 6(1): 166169.

Kim, I.-H., 1996. Copepoda of Artotrogidae (Siphonostomatoida) from the Sea of Japan. Korean J. Syst. Zool., 12(4): 397466.

McKinnon, A.D., 1988. Five artotrogid copepods (Siphonostomatoida) from southern Australia. Invertebr. Taxon., 2: 973993.

Nicholls, A.G., 1944. Littoral copepods from South Australia. (II) Calanoida, Cyclopoida, Notocelphyoida, Monstrilloida and Caligoida. Rec. S. Aust. Mus., 8: 1-62.

Sars, G.O., 1915. An account of the Crustacea of Norway with short descriptions and figures of all the species. Vol. VI, Copepoda Cyclopoida, Parts IX \& X, Ascomyzontidae (concluded), Acontiophoridae, Myzopontidae, Dyspontiidae, Artotrogidae, Cancerillidae. Bergen Museum, pp. 105-140, pls. 65-90. 